\title{
In vitro correlation and analysis of anti-oxidant and anti-inflammatory activities by fruit ripening of peach cultivars
}

\author{
Kyung-Mi Jung ${ }^{1,2}$, San Yeong Kim ${ }^{1}$, Sang-Han Lee ${ }^{2,3 *}$ \\ ${ }^{1}$ Cheongdo Peach Research Institute, GyeongSangBuk-Do Agricultural Technology Administration, Cheongdo 38315, Korea \\ ${ }^{2}$ School of Food Science and Biotechnology, Kyungpook National University, Daegu 41566, Korea \\ ${ }^{3}$ Food and Bio-industry Research Institute, Kyungpook National University, Daegu 41566, Korea
}

\section{복숭아 품종별 성숙정도에 따른 항산화 및 항염증 효과간의 상관관계}

\author{
정경미 ${ }^{1,2} \cdot$ 김산영 $^{1} \cdot$ 이상한 $2,3 *$ \\ ${ }^{1}$ 경북농업기술원 청도복숭아연구소, ${ }^{2}$ 경북대학교 식품공학부 식품생물공학전공, ${ }^{3}$ 식품생물산업연구소
}

\begin{abstract}
This study was performed to investigate the correlation between anti-oxidant and anti-inflammatory activities in ripe and unripe fruits of three peach cultivars: Miwhang (MH), Kanoiwa hakuto (KH) and Cheonhong (CH). The unripe fruits had higher levels of total phenols and flavonoids contents than those in the ripe fruits of all the three cultivars. The unripe fruits of $\mathrm{CH}$ showed the highest levels of total phenols, flavonoids and antioxidant activities among the fruit samples analyzed. Nitric oxide inhibition values in RAW 264.7 cells for the unripe fruits of $\mathrm{MH}$ and $\mathrm{KH}$ were 30 and $29 \%$, respectively. However, the inhibition was not observed in unripe $\mathrm{CH}$ and the ripe fruits of either cultivar. Total phenols and flavonoids contents showed high linear correlations with the anti-oxidant activities whereas the anti-inflammatory activity had low linear correlations with them.
\end{abstract}

Key words : Prunus persica, unripe, mature, anti-oxidant, anti-inflammatory

\section{서 론}

복숭아(Prunus persica L. Batsch)는 장미과(Rosaceae), 자 두속(Prunus), 복숭아과속(Amygdalus)에 속하는 온대 낙엽 성 과수로 우리나라 5 대 과일 중의 하나이며 주성분은 수분 과 당분으로 이루어져 있으며 유기산, 에스테르, 펙틴 등이 풍부하고(1,2), 과육은 aspartic acid와 serine의 함량이 높으 며 유리 아미노산을 많이 함유하고 있다(3).

복숭아는 재배과정에서 과실의 크기를 크고 고르게 하고 품질을 높여주기 위해 4월 초순-5월 초순에 몇 차례 적과를 실시하며, 전체 과실의 $90 \%$ 이상을 차지하는 적과된 미숙

*Corresponding author. E-mail : sang@knu.ac.kr Phone : 82-53-950-7754, Fax : 82-53-950-6772

Received 8 June 2017; Revised 25 July 2017; Accepted 28 July 2017.

Copyright (c) The Korean Society of Food Preservation. All rights reserved.
과는 전량 폐기되고 있는 실정이다. 이런 미숙과에 관한 연구로는 성숙과와 비교하여 페놀 함량, 섬유소, 비타민 등에 많은 차이가 있고(4), 국내 복숭아 미숙과의 품종별 성분 분석에서 환원당 함량이 $6.34 \%$ 이상의 높은 수치를 보여 식품산업 소재로서 가치가 있다(5). 또한 국내외 복숭 아 미숙과에 관한 연구로는 복숭아 미숙과 섭취에 따른 용혈성 빈혈 개선(6), 복숭아의 성숙에 따른 polygalacturonase 활성(7) 및 미백 연구(8) 등이 있다.

최근 노화와 성인병 질환의 원인이 활성산소에 기인된 것이라는 학설이 점차 인정됨에 따라 활성산소를 조절 할 수 있는 물질로 알려진 항산화제 개발 연구가 활발하게 진행되었다(9-12). 또한 항산화 효과를 가지는 물질들이 항 염증 효과를 가질 수 있다는 연구와 연계하여 항산화 효과 와 함께 hyaluronidase저해에 의한 항염증 효과를 가진 물질 들을 천연자원으로부터 검토한 연구 결과가 보고되고 있다 $(13,14)$. 복숭아 관련 항산화 및 항염증 연구에서는 야생 복숭아 가지의 에틸아세테이트 추출물이 천연 항산화제인 tocopherol 및 합성 항산화제인 $\mathrm{BHA}$ 보다 탁월한 항산화 
효과를 나타내고, hyaluronidase 저해에 의한 항염증 효과 시험에서는 항염증 표준품인 ketoprofen보다는 활성이 낮으 나, ibuprofen과 indomethacin보다는 높은 항염증 효과가 나 타난다는 연구가 보고되었다(15). 저장성 시험에서는 $46^{\circ} \mathrm{C}$ 의 열풍 처리로 전반적인 품질은 우수해졌으며, 폴리페놀 및 플라보노이드 함량과 이에 따른 항산화 활성은 대조군과 큰 차이를 보이지 않았고(16), 복숭아 과피와 과육의 에틸아 세테이트 추출물은 positive control인 ascorbic acid에 견줄 만한 높은 항산화 활성과 항균 활성을 가진다고 보고되었다 (17).

한편, 과실은 수확의 시기나 성숙에 따라 성분 및 이로 인한 생리활성에 특이성을 가진다. 블랙 라스베리 과실은 자유 라디칼 소거능 및 환원력 모두 과실이 성숙함에 따라 감소하며, 총 페놀 함량 및 비타민 함량 역시 과실이 성숙함 에 따라 감소하는 것으로 알려 졌으며(18), 딸기의 경우 품종에 따라서 미숙과의 항산화 물질 및 항산화능이 차이가 남을 확인 하였다(19). 하지만, 복숭아의 경우 품종별 성분 분석(5), 추출물을 이용한 소재개발연구(20) 등에 대한 연구 가 있지만 성숙도에 따른 항산화 및 항염증 효능을 파악한 연구는 아직 보고되지 않고 있다.

따라서, 본 연구는 복숭아를 품종 및 성숙도에 따른 항산 화 및 항염증 효과간의 상관관계 등을 분석함으로써 향후 염증 및 산화스트레스와 관련된 질병의 예방과 치료에 대한 기능성 후보 소재를 발굴하고자 수행하게 되었다.

\section{재료 및 방법}

\section{실험재료}

본 연구에 사용한 복숭아는 2014년 경상북도 농업기술원 청도복숭아시험장에서 수확한 품종으로 외관이 양호하고 신선한 것으로 균일하게 선정하였다. 미숙과는 5월 하순에 적과한 것을 이용하였고, 성숙과의 경우 미황(Mihwang)은 6월 하순, 가납암백도(Kanoiwa Hakuto)와 천홍(Cheonhong) 은 7월 하순에 각각 수확하여 실험에 사용하였다. 각 품종별 과실 특성은 Table 1 과 같다.

\section{분석 시료 준비}

미숙과는 경핵 이전의 상태이므로 통째로 사용하였고, 성숙과는 핵과 과육을 분리한 후 과육 부분만을 사용하였
다. 이들을 동결 건조한 후 분쇄하여 분말화한 것을 polyethylene bag으로 포장하여 $-40^{\circ} \mathrm{C}$ 에서 냉동 보관 후 사 용하였다.

분석 시료는 건조 분말 $5 \mathrm{~g}$ 에 $80 \%$ 에탄올 용매를 $1: 10$ 비율로 넣고 1 일간 진탕배양기에서 추출한 후 여과지(No. 2, Whatman ${ }^{\mathrm{TM}}$ International Ltd., Maidstone, UK)로 여과하 여 얻은 용액을 감압농축기(OSB-2000, Eyela Co., Tokyo, Japan)로 농축한 후 동결 건조하여 $100 \mathrm{mg} / \mathrm{mL}$ 의 농도를 최종 농도로 설정하여 실험에 사용하였다.

\section{표준 화합물과 검량선 작성}

분석을 위해 3종의 플라보노이드 화합물인 amygdalin, catechin, chlorogenic acid를 사용하였으며, 검량선 작성을 위하여 상기 3종의 플라보노이드 표준 화합물을 메탄올에 녹여서 $50,100,250,500 \mu \mathrm{g} / \mathrm{mL}$ 농도의 표준액을 제조한 후 UPLC chromatogram을 산출하였다 $\left(\mathrm{R}^{2}>0.990\right)$.

\section{UPLC를 이용한 물질 분석}

전 처리한 각각의 시료 $1 \mathrm{~g}$ 을 메탄올 $40 \mathrm{~mL}$ 에 녹이고 $40^{\circ} \mathrm{C}$ 에서 2 시간 동안 초음파 분쇄를 한 후 여과한 다음 rotatory evaporator를 이용하여 감압 하에 농축시키고 동결 건조하였다. 건조된 추출물을 증류수 및 메탄올에 각각 25 $\mathrm{mg} / \mathrm{mL}$ 의 농도로 녹이고 $0.2 \mu \mathrm{m}$ syringe filter에 여과한 후 $1 \mu \mathrm{L}$ 를 Acquity UPLC H-Class(Waters, Milford, MA, USA) 를 이용하여 분석하였다(21). 이동상으로는 용매 $\mathrm{A}(1 \%$ formic acid in water) 및 용매 $\mathrm{B}(0.1 \%$ formic acid in methanol)를 사용하였다. 유속은 $0.3 \mathrm{~mL} / \mathrm{min}$ 으로 일정하게 흘려주었으며, gradient elution은 다음과 같이 수행하였다. $7 \%$ 의 $\mathrm{B}$ 용매로 시작하여 2 분까지 $7 \%, 5$ 분까지 $17 \%$ 로 증가 시킨 후 10 분까지 $17 \%$ 를 유지하였다. 그리고 12 분까지 $25 \%$ 로 증가시킨 후 17 분까지 $25 \%$ 를 유지하였으며, 19 분까 지 $50 \%$ 로 증가시킨 후, 24 분까지 $50 \%$ 를 유지하였다. 이어 서 26분까지 $90 \%$ 로 증가시킨 후, 30 분까지 $90 \%$ 를 유지하 였으며 다시 1 분 동안 $7 \%$ 로 되돌아온 후 4 분간 안정화시켰 다. 검출기는 $\mathrm{UV}$ 검출기를 사용하였고 고정된 파장 259 $\mathrm{nm}$ 에서 검출하였다.

\section{총 페놀 함량 분석}

Total phenol 함량 측정은 Folin-Denis 방법(22)을 변형하 여 측정하였다. 96-well plate에 농도별 시료액 $2 \mu \mathrm{L}$ 를 증류

Table 1. Quality characteristics of peaches fruit

\begin{tabular}{cccccccc}
\hline Cultivars $^{1)}$ & Ripening time (month/day) & Weight $(\mathrm{g})$ & sugar content $\left({ }^{\circ}\right.$ Brix $)$ & Total acidity $(\%)$ Hardness $(\mathrm{kg} / \varnothing 5 \mathrm{~mm})$ & Hairy/Hairless & Color \\
\hline $\mathrm{MH}$ & $6 / 28$ & 250 & 11.5 & 0.13 & 0.53 & Hairy & Yellow \\
$\mathrm{CH}$ & $7 / 20$ & 245 & 10.8 & 0.80 & 1.43 & Hairless & Yellow \\
$\mathrm{KH}$ & $7 / 19$ & 251 & 11.8 & 0.12 & 0.92 & Hairy & White \\
\hline
\end{tabular}

${ }^{1)} \mathrm{MH}$, Mihwang; KH, Kanoiwa Hakuto; CH, Cheonhong. 
수 $20 \mu \mathrm{L}$ 와 Folin Ciocalteu's phenol reagent를 $10 \mu \mathrm{L}$ 첨가하 여 실온에서 6 분간 incubation 시킨 후 $7 \% \mathrm{Na}_{2} \mathrm{CO}_{3}$ solution $100 \mu \mathrm{L}$ 와 증류수 $70 \mu \mathrm{L}$ 를 첨가하여 실온에서 90 분간 incubation 시킨 후 $595 \mathrm{~nm}$ 에서 흡광도를 측정하였다. 표준 물질로는 gallic acid를 사용하였으며 시료와 동일한 방법으 로 분석하여 검량선을 작성한 후 total phenol 함량을 산출하 였다.

\section{총 플라보노이드 함량 분석}

Total flavonoid 함량 측정은 Zhishen 등(23)과 Singleton 등(24)의 방법을 변형하여 측정하였다. 96-well plate에 농도 별 시료액 $2 \mu \mathrm{L}$ 를 증류수 $100 \mu \mathrm{L}$ 와 $5 \% \mathrm{NaNO}_{2}$ solution $5 \mathrm{LL}$ 를 혼합하여 실온에서 10 분간 incubation 시키고, $10 \%$ $\mathrm{AlCl}_{3} \cdot 6 \mathrm{H}_{2} \mathrm{O}$ solution $10 \mu \mathrm{L}$ 를 첨가하여 다시 실온에서 10 분 간 incubation 시킨 후 $1 \mathrm{M} \mathrm{NaOH} 40 \mu \mathrm{L}$ 와 증류수 $45 \mu \mathrm{L}$ 를 첨가하여 $405 \mathrm{~nm}$ 에서 흡광도를 측정하였다. 표준물질로는 catechin을 사용하였으며 시료와 동일한 방법으로 분석하 여 검량선을 작성한 후 total flavonoid 함량을 산출하였다.

\section{2,2-Diphenyl-2-picrylhydrazyl(DPPH) 라디칼 소거}

\section{활성 측정}

$\mathrm{DPPH}$ 라디컬 소거 활성 측정은 Blois의 방법(25)을 변형 하여 측정하였다. 96-well plate에 농도별 추출물 $2 \mu \mathrm{L}$ 를 주입하고 50\% 메탄올에 녹인 $40 \mathrm{mM}$ DPPH solution을 198 $\mu \mathrm{L}$ 가하여 총 부피가 $200 \mu \mathrm{L}$ 가 되도록 하였다. 이 반응액을 실온에 약 10 분간 방치한 후 분광광도계로 $517 \mathrm{~nm}$ 에서 흡광도를 측정하였다. 활성도는 추출물의 첨가구와 무 첨 가구의 흡광도를 통해 백분율로 나타낸 다음 농도별 검량선 에 대비하여 $\mathrm{IC}_{50}$ (half maximal inhibitory concentration)으로 나타내었다.

$\mathrm{DPPH}$ radical scavenging activity $(\%)=\left(\frac{\mathrm{A} \text { control-A sample }}{\mathrm{A} \text { control }}\right) \times 100$

A : absorbance at OD $517 \mathrm{~nm}$

\section{FRAP assay에 의한 환원력 측정}

Ferric ion reducing antioxidant power(FRAP) assay는 Benzie와 Strain의 방법(26)을 변형하여 측정하였다. 실험을 위한 FRAP solution은 acetate buffer(pH 3.6, $300 \mathrm{mM})$, 2,4,6-tripyridyl-s-triazine(TPTZ) $10 \mathrm{mM}, \mathrm{FeCl}_{3} \cdot 6 \mathrm{H}_{2} \mathrm{O} 20 \mathrm{mM}$ 을 10:1:1의 부피비로 섞어 실험 직전에 만들어 사용하였다. 양성 대조군은 ascorbic acid를 사용하였고, 시료를 96-well plate에 각각 $6 \mu \mathrm{L}$ 주입한 후 FRAP solution $194 \mu \mathrm{L}$ 를 가하여 실온에서 빛을 차단한 상태로 10 분 동안 incubation 시킨 후 $595 \mathrm{~nm}$ 에서 흡광도를 측정하였다.

\section{CUPRAC assay에 의한 환원력 측정}

Cupric ion reducing antioxidant capacity(CUPRAC) assay 는 구리 이온의 환원력을 이용하여 radical을 환원시킬 수 있는지의 활성을 확인하는 방법으로 Apak의 방법(27)을 변형하여 측정하였다. DW: $10 \mathrm{mM} \mathrm{CuCl}: 75 \mathrm{mM}$ Neocuproine 을 100:1:1의 부피비로 혼합하여 실험 직전에 사용하였다. FRAP assay와 마찬가지로 양성 대조군은 ascorbic acid를 사용하였고, 시료를 96-well plate에 각각 $6 \mu \mathrm{L}$ 주입하고 CUPRAC solution $194 \mu \mathrm{L}$ 를 가한 후 $37^{\circ} \mathrm{C}$ 에서 빛을 차단한 상태로 20 분간 incubation한 후 $450 \mathrm{~nm}$ 에서 흡광도를 측정 하였다.

\section{ABTS 라디칼 소거 활성 측정}

$\mathrm{Re}$ 의 방법(28)을 변형하여 2,2'-azinobis-(3-ethylbenzothiazoline-6-sulfonic acid) 양이온 소거능을 측정하였다. 1 $\mathrm{mM} \mathrm{AAPH}$ 와 $2.5 \mathrm{mM} \mathrm{ABTS}$ 용액을 $68^{\circ} \mathrm{C}$ 에서 30 분간 반응 시킨 ABTS solution을 만들어 실험에 사용하였다. 각 시료 를 $100,200,400 \mu \mathrm{g} / \mathrm{mL}$ 농도로 만들어 $20 \mu \mathrm{L}$ 를 취해 980 $\mu \mathrm{L} \mathrm{ABTS}$ solution에 첨가한 뒤 일정 시간동안 반응시키면 서 $734 \mathrm{~nm}$ 에서 감소하는 흡광도 값을 측정하였다. 대조군 은 메탄올 $20 \mu \mathrm{L}$ 를 첨가해 흡광도를 측정하였으며, 활성도 는 DPPH 방법과 마찬가지로 $\mathrm{IC}_{50}$ (half maximal inhibitory concentration)으로 나타내었다.

ABTS radical scavenging activity $(\%)=\left(\frac{\text { A control-A sample }}{\text { A control }}\right) \times 100$

A : absorbance at OD $734 \mathrm{~nm}$

\section{세포배양}

본 실험에 사용된 대식세포주인 murine macrophage RAW 264.7 세포는 한국세포주은행(Korean Cell Line Bank, Seoul, Korea)에서 분양 받았으며, $10 \% \mathrm{FBS}$, penicillin G $(100 \mathrm{IU} / \mathrm{mL})$ 와 streptomycin $(100 \mu \mathrm{g} / \mathrm{mL})$ 이 첨가된 DMEM 배지를 사용하여 $\mathrm{CO}_{2}$ incubator $\left(5 \% \mathrm{CO}_{2}, 95 \%\right.$ air)에서 $37^{\circ} \mathrm{C}$ 의 조건으로 배양하였다.

\section{세포독성}

RAW 264.7 세포에서 복숭아 추출물의 세포 독성을 확인 하기 위해 MTT assay를 실시하였다. RAW 264.7 세포를 $5 \times 10^{5}$ cells $/ \mathrm{mL}$ 의 농도로 96-well plate에 접종하고, 1 시간 배양 후 시료 $2 \mu \mathrm{L}$ 를 농도별로 처리하여 1 시간 동안 배양하 였다. 시료가 처리된 세포에 LPS를 $1 \mathrm{\mu g} / \mathrm{mL}$ 의 농도로 처리 한 후 $37^{\circ} \mathrm{C}$ 에서 22 시간 배양하였다. 배지에 희석된 MTT 용액 $(0.5 \mathrm{mg} / \mathrm{mL})$ 을 세포에 1시간 처리한 후, MTT를 환원시 켜 생성된 formazan이 배지에서 분리되지 않도록 배지를 제거하였다. 생성된 MTT-formazan은 DMSO에 용해시켜 ELISA reader를 이용하여 $540 \mathrm{~nm}$ 에서 흡광도를 측정하 
였다.

\section{Nitric oxide(NO) 소거 활성 측정}

RAW 264.7 세포를 $5 \times 10^{5}$ cells $/ \mathrm{mL}$ 의 농도로 96-well plate 에 접종한 후 농도별로 시료를 처리하고 LPS를 $1 \mu \mathrm{g} / \mathrm{mL}$ 이 되도록 가하여 24시간 배양하였다. 세포 상등액에 생성된 NO의 양은 griess reagent( $1 \%$ sulfanilic acid: $1 \%$ napthylamine $=1: 1$ )를 이용하여 상등액과 $1: 1$ 의 비율로 혼합한 후 490 $\mathrm{nm}$ 에서 흡광도를 측정하였다.

\section{통계처리}

통계처리는 각 그룹 간의 차이를 보기위해 SAS프로그램 을 이용하여 분산분석(analysis of variance)을 실시하고 유 의수준 $\mathrm{p}<0.05$ 에서 유의적인 차이를 보인 경우 Duncan의 다중범위 시험법(Duncan' multiple arange test)을 적용하여 사후분석을 실시하였다.

\section{결과 및 고찰}

\section{총 페놀 함량 및 총 플라보노이드 함량}

성숙 정도에 따른 품종별 복숭아의 총 페놀 및 플라보노 이드 함량을 측정한 결과는 Table 2 와 같다. 페놀 화합물은 식물계에 널리 분포되어 있으며 분자 내 다수의 phenolic hydroxyl기를 가지고 있고, 단백질 및 여러 화합물과 쉽게 결합하는 특성을 가지고 있어 항산화 효과 및 항암, 항염증 효과가 있는 것으로 보고되었다(29-31). 미황, 가납암백도, 천홍 미숙과의 총 페놀 함량은 각각 $24.34 \pm 0.53 \mathrm{mg} \mathrm{GAE} / \mathrm{g}$, $24.75 \pm 1.56 \mathrm{mg} \mathrm{GAE} / \mathrm{g}, 64.99 \pm 0.22 \mathrm{mg} \mathrm{GAE} / \mathrm{g}$ 으로 나타나 천홍 미숙과의 페놀 함량이 다른 품종들에 비해 약 2.7 배 더 높은 함량을 보였다 $(\mathrm{p}<0.05)$. 반면, 성숙과의 총 페놀 함량은 미황, 가납암백도, 천홍 각각 $15.86 \pm 0.29 \mathrm{mg} \mathrm{GAE} / \mathrm{g}$, $9.02 \pm 0.35 \mathrm{mg} \mathrm{GAE} / \mathrm{g}, 9.30 \pm 0.29 \mathrm{mg} \mathrm{GAE} / \mathrm{g}$ 으로 미황 성숙 과가 다른 품종에 비해 약 1.7 배 더 높은 함량을 나타냈다 $(\mathrm{p}<0.05)$. 플라보노이드는 식물체에 다양하게 존재하는 색

Table 2. Total phenols and total flavonoids contents according to fruit ripening of peaches

\begin{tabular}{ccccc}
\hline \multirow{2}{*}{ Cultivars $\left.{ }^{1}\right)$} & \multicolumn{2}{c}{ Total phenol $\left(\mathrm{mg} \mathrm{GAE}^{2} / \mathrm{g}\right)$} & \multicolumn{2}{c}{ Total flavonoid $\left(\mathrm{mg} \mathrm{CE}^{3} / \mathrm{g}\right)$} \\
\cline { 2 - 5 } & Unripe & Mature & Unripe & Mature \\
\hline $\mathrm{MH}$ & $24.34 \pm 0.53^{4) \mathrm{b} 5}$ & $15.86 \pm 0.29^{\mathrm{a}}$ & $24.17 \pm 9.73^{\mathrm{b}}$ & $8.25 \pm 0.21^{\mathrm{a}}$ \\
$\mathrm{KH}$ & $24.75 \pm 1.56^{\mathrm{b}}$ & $9.02 \pm 0.35^{\mathrm{b}}$ & $25.41 \pm 1.19^{\mathrm{b}}$ & $5.92 \pm 0.00^{\mathrm{b}}$ \\
$\mathrm{CH}$ & $64.99 \pm 0.22^{\mathrm{a}}$ & $9.30 \pm 0.29^{\mathrm{b}}$ & $68.24 \pm 10.86^{\mathrm{a}}$ & $4.83 \pm 0.17^{\mathrm{b}}$ \\
\hline
\end{tabular}

${ }^{1)} \mathrm{MH}$, Mihwang; KH, Kanoiwa Hakuto; CH, Cheonhong.

${ }^{2)}$ Expressed as $\mathrm{mg}$ gallic acid equivalent.

${ }^{3)}$ Expressed as $\mathrm{mg}$ catechin equivalents.

${ }^{4)}$ Values are means $\pm \mathrm{SD}$ of triplicate determinations.

${ }^{5}$ Different letters in the same column indicate significantly different at $p<0.05$.
소로서 페놀에 속하는 성분이다. 항산화능이 높으며 병원 균 억제, 자외선 차단, 항염, 항균, 항바이러스, 지질저하 작용, 항알레르기 등의 효과가 알려져 있다(32-34). 미숙과 의 품종별 플라보노이드 함량은 미황, 가납암백도, 천홍 각각 $24.17 \pm 9.73 \mathrm{mg} \mathrm{CE} / \mathrm{g}, 25.41 \pm 1.19 \mathrm{mg} \mathrm{CE} / \mathrm{g}, 68.24 \pm$ $10.86 \mathrm{mg} \mathrm{CE} / \mathrm{g}$ 으로 나타나 천홍 미숙과가 다른 품종들에 비해 약 2.8 배 높은 총 플라보노이드 함량을 나타냈다 $(\mathrm{p}<0.05)$. 반면 성숙과의 품종별 플라보노이드 함량은 미황, 가납암백도, 천홍 각각 $8.25 \pm 0.21 \mathrm{mg} \mathrm{CE} / \mathrm{g}, 5.92 \pm 0.00 \mathrm{mg}$ $\mathrm{CE} / \mathrm{g}, 4.83 \pm 0.17 \mathrm{mg} \mathrm{CE} / \mathrm{g}$ 으로, 미황 성숙과가 다른 품종에 비해 플라보노이드의 함량이 높은 것으로 나타났다. 이에 따라 미숙과와 성숙과의 플라보노이드 및 페놀의 함량을 비교하였으며, 미숙과가 성숙과에 비해 항산화성 물질인 플라보노이드 및 페놀의 함유량이 더 높다는 결과를 얻을 수 있었다.

\section{항산화 활성}

복숭아 품종별 성숙도에 따른 항산화 활성 결과는 Table 3 과 같다. 복숭아 품종별에 따른 미숙과의 DPPH 라디칼 소거능을 비교한 결과, 천홍 미숙과가 $264.0 \mu \mathrm{g} / \mathrm{mL}$ 의 농도 에서 $\mathrm{IC}_{50}$ 을 보여 가장 높은 활성을 나타냈으며, 천홍 다음 으로 미황, 가납암백도 순으로 나타났다. 성숙과 중에서는 미황이 가장 높은 $412.9 \mu \mathrm{\mu g} / \mathrm{mL}$ 의 농도에서 $\mathrm{IC}_{50}$ 을 나타냈으 며, 미황 다음으로 천홍, 가납암백도 순으로 나타나 미숙과 와 성숙과의 항산화 활성이 차이가 나타났다. 항산화 관련 연구에 따르면 높은 페놀 함량이 높은 항산화 활성을 나타 내는 것으로 보고되어 있으며(35), 이는 총 페놀과 플라보노 이드 함량이 가장 높은 천홍 미숙과가 DPPH 라디칼 소거능 이 우수한 것으로 나타나 DPPH 라디칼 소거능은 총 페놀과 플라보노이드 함량과의 관련이 있음을 시사한다(Table 4).

ABTS 용액과 potassium persulfate를 암실에서 반응시키 면 청록색 $\mathrm{ABTS}$ 라디칼(ABTS-+)이 생성되고 시료 중에 항산화 활성을 갖는 물질이 존재하면 $\mathrm{ABTS}$ 라디칼이 소거 되어 탈색되면서 흡광도 변화를 나타내게 된다. 이 방법은 친수성 및 소수성 물질의 항산화 활성 측정에 모두 적용할 수 있으며, 단 시간 내에 라디칼 소거능을 측정함으로써 다른 작용기를 갖는 항산화 능력을 측정할 수 있는 장점이 있다. 복숭아 품종별 미숙과와 성숙과의 ABTS 라디칼 소거 능을 측정한 결과, 미숙과에서 천홍, 가납암백도, 미황 순으 로 각각 $242.7,467.3,490.2 \mathrm{\mu g} / \mathrm{mL}$ 의 농도에서 $\mathrm{IC}_{50}$ 을 나타 낸 반면 성숙과에서는 활성이 관찰되지 않았다. 천홍 미숙 과가 가장 우수한 ABTS radical 소거능을 보였으며, 이는 천홍 미숙과의 총 페놀 및 플라보노이드 함량이 다른 품종 에 비해 가장 높았기 때문에 항산화 활성에 영향을 준 것으 로 판단된다.

FRAP 활성은 화합물의 환원력(ferric reducing ability)을 측정하는 것으로 ferric tripyridyltriazine $\left(\mathrm{Fe}^{3+}-\mathrm{TPTZ}\right)$ 이 환원 
Table 3. Antioxidant activity peaches cultivars using ABTS, DPPH, ferric ion reducing antioxidant power (FRAP), and cupric ion reducing antioxidant capacity (CUPRAC) assays

\begin{tabular}{|c|c|c|c|c|c|c|c|c|}
\hline \multirow[t]{2}{*}{ Cultivars ${ }^{1)}$} & \multicolumn{2}{|c|}{$\begin{array}{c}\text { ABTS } \\
\mathrm{IC}_{50}(\mu \mathrm{g} / \mathrm{mL})\end{array}$} & \multicolumn{2}{|c|}{$\begin{array}{c}\text { DPPH } \\
\text { IC }_{50}(\mu \mathrm{g} / \mathrm{mL})\end{array}$} & \multicolumn{2}{|c|}{$\begin{array}{c}\text { FRAP } \\
\text { Fold (of control) } \\
\end{array}$} & \multicolumn{2}{|c|}{$\begin{array}{c}\text { CUPRAC } \\
\text { Fold (of control) }\end{array}$} \\
\hline & Unripe & Mature & Unripe & Mature & Unripe & Mature & Unripe & Mature \\
\hline $\mathrm{MH}$ & 490.2 & $\mathrm{ND}^{2)}$ & 337.2 & 412.9 & $6.1 \pm 0.2^{3 \mathrm{bb4})}$ & $5.6 \pm 0.2^{a}$ & $6.0 \pm 0.1^{b}$ & $5.9 \pm 0.5^{\mathrm{a}}$ \\
\hline $\mathrm{KH}$ & 467.3 & $\mathrm{ND}$ & 372.0 & 813.8 & $5.3 \pm 0.1^{b}$ & $3.5 \pm 0.0^{\mathrm{a}}$ & $5.9 \pm 0.1^{b}$ & $4.0 \pm 0.0^{\mathrm{a}}$ \\
\hline $\mathrm{CH}$ & 242.7 & ND & 264.0 & 635.3 & $8.4 \pm 0.3^{\mathrm{a}}$ & $3.5 \pm 0.0^{\mathrm{a}}$ & $8.4 \pm 0.3^{\mathrm{a}}$ & $4.1 \pm 0.0^{\mathrm{a}}$ \\
\hline
\end{tabular}

${ }^{1)} \mathrm{MH}$, Mihwang; KH, Kanoiwa Hakuto; CH, Cheonhong.

${ }^{2)}$ Not Detected.

${ }^{3)} \mathrm{Mean} \pm \mathrm{SD}(\mathrm{n}=3)$.

${ }^{4}$ Different letters in the same column indicate significantly different at $\mathrm{p}<0.05$.

Table 4. Pearson's correlation coefficients of ABTS, DPPH, CUPRAC, FRAP, total phenol content (TPC), total flavonoid content (TFC), nitric oxide activity in RAW 264.7 cells

\begin{tabular}{cccccccc}
\hline & ABTS & DPPH & CUPRAC & FRAP & NO in RAW 264.7 & TPC & TFC \\
\hline ABTS & 1 & $0.908^{* 1)}$ & $0.886^{*}$ & $0.886^{*}$ & -0.797 & $0.938^{* *}$ & $0.963^{* *}$ \\
DPPH & - & 1 & $0.970^{* *}$ & $0.970^{* *}$ & -0.707 & $0.889^{*}$ & $0.883^{*}$ \\
CUPRAC & - & - & 1 & $0.994^{* *}$ & -0.576 & $0.938^{* *}$ & $0.917^{* *}$ \\
FRAP & - & - & - & 1 & -0.569 & $0.936^{* *}$ & $0.918^{* *}$ \\
NO in RAW 264.7 & - & - & - & - & - & -0.546 & -0.606 \\
TPC & - & - & - & - & - & - & $0.995^{* *}$ \\
TFC & - & - & - & - & - & - & 1 \\
\hline
\end{tabular}

$1)^{*}, \mathrm{p}<0.05 ;{ }^{* *}, \mathrm{p}<0.01$

제에 의해서 파란색의 ferrous tripyridyltriazine $\left(\mathrm{Fe}^{2+}-\mathrm{TPTZ}\right)$ 으로 환원되는 원리를 이용한 것이며, 이는 DPPH 및 ABTS 실험방법과는 다른 메커니즘의 항산화 활성 측정 방법이다 (35). 복숭아의 성숙정도에 따른 품종별 FRAP value를 확인 한 결과, 대조군에 비해 미숙과에서 천홍, 미황, 가납암백도 가 8.4배, 6.1배, 5.3배로 천홍이 가장 높은 활성을 나타난 반면, 성숙과에서는 유의적 차이가 나타나지 않았다.

CUPRAC 활성은 환원제(antioxidant)에 의해서 구리이온 $\left(\mathrm{Cu}^{2+}\right)$ 이 환원되는 원리를 이용하여 항산화 활성을 측정하 는 방법이다(36). 품종별 미숙과 추출물에서는 대조군 대비 천홍이 8.4배의 활성이 나타났으며, 미황과 가납암백도와 비교하여 유의적 활성이 관찰되었지만, 성숙과에서는 FRAP 결과와 마찬가지로 유의적 차이가 나타나지 않았다. 이에 따라 복숭아의 품종별 성숙정도에 따른 항산화 실 험 결과를 토대로 성숙과에 비해 미숙과의 항산화 활성이높 았으며, 품종별로는 천홍의 활성이 가장 우수하였다. 이는 총 페놀 및 플라보노이드의 함량이 우수함에 따라 높은 항산화 활성을 보여, 페놀 및 플라보노이드와 $\mathrm{DPPH}, \mathrm{ABTS}$ 및 CUPRAC assay 간의 관련이 있음을 보여준다.

\section{$\mathrm{UPLC}$ 를 이용한 성분분석}

복숭아에 함유되어 있는 주된 생리활성 화합물은 클로로 겐산(chlorogenic acid), 카테킨(catechins), 아미그달린 (amygdalin) 등 이 알려져 있다(3). 이에 위 3종의 화합물을 표준 물질로 사용하였고, UPLC 크로마토그래피를 이용하 여 Fig. 1에 나타냈다. 복숭아 3종의 미숙과 추출물의 함유 성분에 대한 UPLC 크로마토그래피를 비교 분석한 결과 유사한 패턴이 관찰되었지만, 각 피크의 함량에는 차이가 나타났다. 클로로겐산의 머무름 시간인 11 분일 때에 모든 샘플에서 나타났으며, 이를 확인하기 위해 $\mathrm{UV}$ 스펙트럼을 관찰한 결과 클로로겐산에서 나타나는 UV 스펙트럼과 유 사한 형상이 관찰되어 클로로겐산으로 확인 하였다(Fig. 2). 또한 20-25분 사이의 피크 패턴이 천홍 미숙과가 미황과 가납암백도 미숙과와의 피크 패턴과 다르게 나오는 것이 확인 되어 천홍 미숙과의 유효성분이 다른 미숙과와 다른 성분이 함유 되어 있을 것으로 예상하였다. 그에 반해 성숙 과의 품종별 UPLC 크로마토그래피는 미숙과에 비해 전체 적으로 피크가 낮게 확인 되었으며, 미숙과에서 관찰된 클 로로겐산의 11 분 피크가 약하게 관찰되었지만, $\mathrm{UV}$ 스펙트 럼을 관찰한 결과 클로로겐산으로는 확인되지 않았다(Fig. 3). 위의 결과는 총 페놀 및 플라보노이드 함량의 관계를 간접적으로 예상하였고, 추후 다른 물질에 대한 확인은 LC-MS 및 NMR 분석을 통한 분석이 필요 할 것으로 예상된 다. 

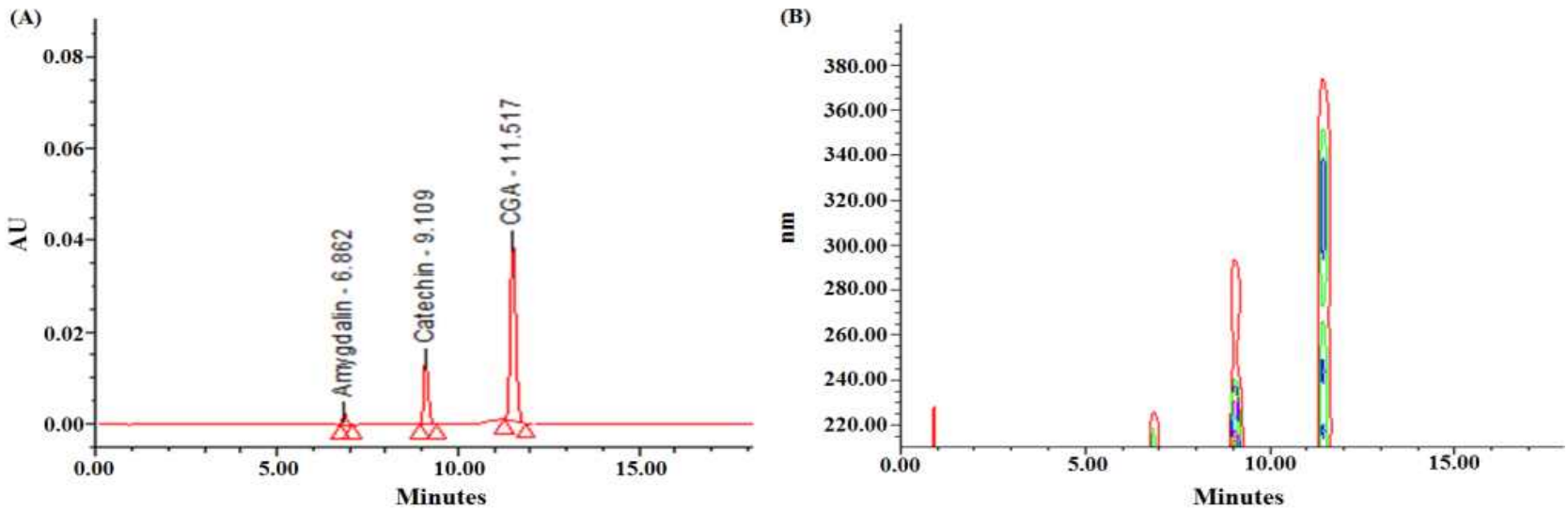

Fig. 1. UPLC chromatograms (A) and UV scan graphic (B) of standard compounds (amygdalin, catechin and chlorogenic acid).
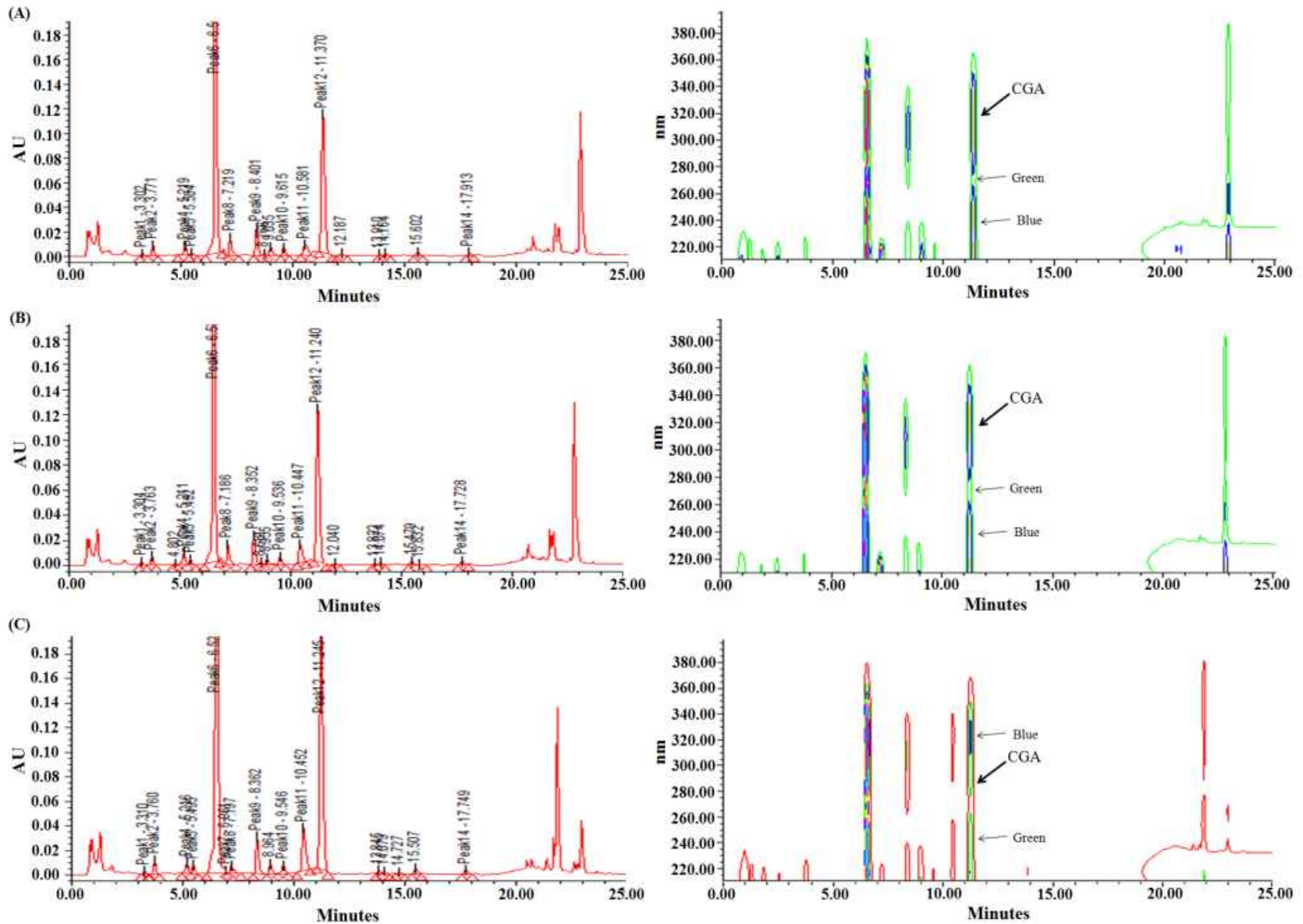

Fig. 2. UPLC chromatograms (left) and UV scan graphic (right) of the unripe extracts of three peach cultivars.

A, Miwhang, B, Kanoiwa Hakuto; C, Cheonhong.

\section{항염증 활성}

본 연구 에서 복숭아 3품종의 성숙과와 미숙과 추출물의 항염증 활성을 조사하기 위해 LPS 자극에 의해 유도된 RAW 264.7 대식세포(macrophage)의 염증 반응에서 NO 억제 활성 실험을 수행하였다. 면역세포중의 하나인 대식 세포는 능동 및 수동 면역반응에서 매우 중요한 역할을
하여 LPS 같은 외부항원 자극 시 종양괴사인자(tumor necrosis factor alpha, TNF-a), 인터루킨 $1 \beta(\mathrm{IL}-1 \beta)$, 인터루킨 6(IL-6)와 같은 다양한 염증매개 물질 등을 유도 하며, 이러 한 염증매개 물질 형성은 NO 형성을 증가 시켜 염증 반응을 촉진 시킨다(37). 

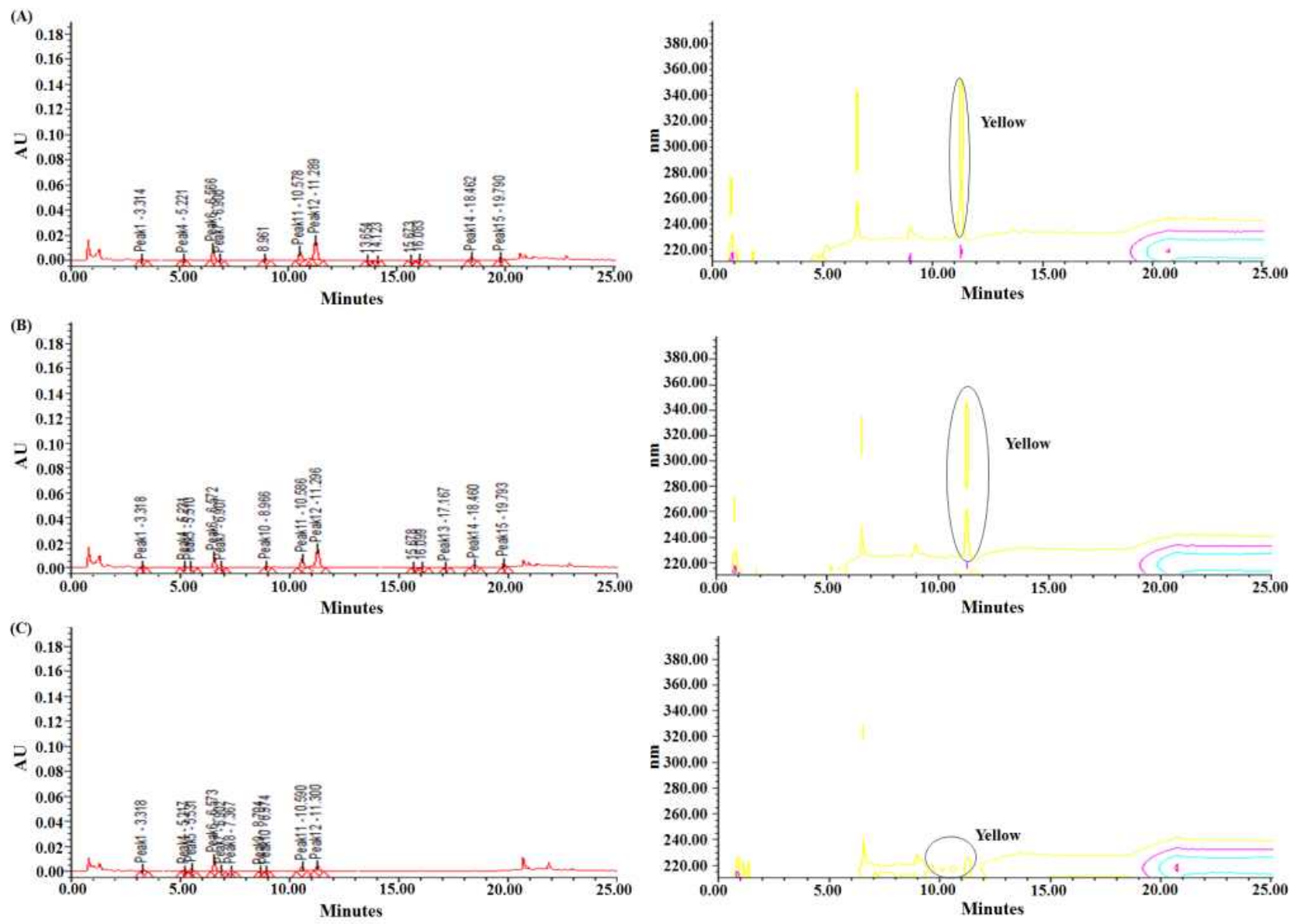

Fig. 3. UPLC chromatograms (left) and UV scan graphic (right) of the ripe extracts of three peach cultivars.

A, Miwhang, B, Kanoiwa Hakuto; C, Cheonhong.

RAW 264.7 세포에서 미황 미숙과의 추출물은 약 $30 \%$ 의 $\mathrm{NO}$ 생성 억제 효과가 관찰되었고, 가납암백도 미숙과가 약 $29 \%$, 천홍 미숙과가 약 $20 \%$ 의 효과가 나타났지만, 복숭 아 성숙과 3품종에서는 활성이 나타나지 않았다(Fig. 4). 본 연구에 따라 성숙과에 비해 미숙과의 항염증 활성이 높게 나타나므로 미숙과 3품종에 대한 항염증 소재 개발의 가능성을 확인 할 수 있었다.

\section{상관관계 분석}

복숭아 3품종의 성숙과와 미숙과의 총 플라보노이드 함 량과 총 페놀 함량과의 상관성이 0.995 로 유의적 $(\mathrm{p}<0.01)$ 으 로 가장 높은 상관관계를 나타냈으며, 항산화 활성간의 상 관성은 FRAP 활성과 CUPRAC 활성 간의 상관성(0.994, $\mathrm{p}<0.01), \mathrm{DPPH}$ 라디칼 소거능과 FRAP 활성 간의 상관성 $(0.970, \mathrm{p}<0.01), \mathrm{ABTS}$ 라디칼 소거능과 $\mathrm{DPPH}$ 라디칼 소거 능 간의 상관성(0.908, $\mathrm{p}<0.05), \mathrm{CUPRAC}$ 활성과 $\mathrm{ABTS}$ 라 디칼 소거능의 상관성 $(0.886, \mathrm{p}<0.05)$ 순으로 모두 유의적인 상관관계가 확인되었다. 또한 총 페놀 함량과 총 플라보노 이드 함량의 항산화 활성들 간의 상관관계에서 고도의 정의 상관성 (0.889-0.968)을 나타내었다. 이는 플라보노이드성

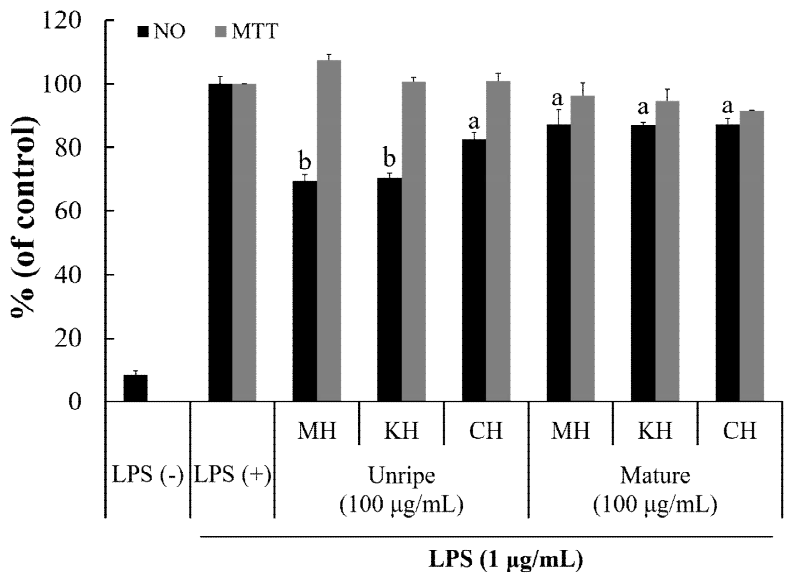

Fig. 4. Effects of fruits ripening of peach on production of nitric oxide and cell viability in RAW 264.7 cells.

MH, Mihwang; KH, Kanoiwa Hakuto; CH, Cheonhong.

Values are means $\pm \mathrm{SD}$ of triplicate determinations. Different superscripts within a column $(\mathrm{a}-\mathrm{b})$ indicate significant differences of $\mathrm{p}<0.05$.

페놀 화합물이 라디칼을 직접 소거하는 항산화 작용뿐만 아니라 환원력에도 관여한다는 것을 확인할 수 있다. 반면, 항염증 활성과 항산화 활성들 간의 상관성은 낮게 확인되었 
다. 또한 항염증 활성과 총 페놀 및 플라보노이드 함량간의 상관성은 낮은 상관관계를 나타내며, 이는 플라보노이드성 페놀 화합물이 항염증 활성에 대한 관여성이 낮다는 것을 확인 할 수 있다(Table 4). 따라서 본 연구에서 복숭아 3품종 의 성숙과와 미숙과의 플라보노이드성 페놀 화합물이 다양 한 항산화 활성에서 효능을 나타내고 있으며, 항염증 활성 에는 비 플라보노이드성 페놀 화합물이 작용 하는 것으로 확인할 수 있었다.

\section{요 약}

본 연구에서는 복숭아의 품종인 미황, 가납암백도 및 천 홍을 성숙정도에 따라 미숙과와 성숙과로 분류하여 항산화 및 항염증 효과간의 상관관계 등을 분석함으로서 향후 염증 및 산화스트레스와 관련된 질병의 예방 또는 치료할 수 있는 기능성 소재를 발굴하고자 수행하였다. 총 페놀 및 플라보노이드 함량은 3품종 모두 성숙과에 비해 미숙과에 서 함량이 많았고, 미숙과 중에서는 천홍이, 성숙과 중에서 는 미황이 유의성 있게 높은 함량을 나타내었다. 항산화 활성은 미숙과 천홍에서 가장 높았고, 성숙과에서는 $\mathrm{DPPH}$ 라디칼 소거능 측정에 의해서는 미황이 유의성 있게 높았으 나 FRAP과 CUPRAC 측정에서는 3품종간 유의적인 차이 가 없었다. RAW 264.7 세포에서는 미황 미숙과 추출물이 약 $30 \%$ 의 NO 생성 억제 효과가 관찰되었고, 가납암백도 미숙과는 약 $29 \%$, 천홍 미숙과는 약 $20 \%$ 의 저해활성을 보이지만, 복숭아 성숙과 3품종에서는 NO 생성 억제 효과 가 나타나지 않았다. 3품종 모두 성숙과에 비해 미숙과에서 저해 활성이 높게 나타났다. 총 페놀 함량과 플라보노이드 함량에 따른 항산화 활성들 간의 상관관계에서 고도의 정의 상관성을 나타내었으며, 항염증 활성과 항산화 활성, 항염 증 활성과 총 페놀 및 플라보노이드 함량은 낮은 상관관계 를 나타내었다.

\section{감사의 글}

본 연구는 경상북도농업기술원 연구기술개발지원 사업 의 연구비 지원에 의해 수행되었으며 이에 감사드립니다.

\section{References}

1. Lee DS, Woo SK, Yang CB (1972) Studies on the chemical composition of major fruits in Korea. Korean J Food Sci Technol, 4, 134-139

2. Song JH, Son MA, Kim MH (1992) Comparison of the cell wall components and polygalacturonase activity in peach types. Korean J Food Nutr, 5, 111-115

3. Lee HB, Yang CB, Yu TJ (1972) Studies on the chemical composition of some fruit vegetables and fruits in Korea (I): on the free amino acid and sugar contents in tomato, watermelon, muskmelon, peach and plum. Korean J Food Sci Technol, 4, 36-43

4. Park YG, Choi IU, Kim HM, Kim SR, Park MW, Cha HS, Choi HD, Suk HM, Kang YH (1999) Studies on the utilization of unripe apples. Report of Ministry of Agriculture and Forestry, GA0108-9910

5. Kim DM, Kim KH, Choi IJ, Yook HS (2012) Composition and phyicochemical properties of unripe Korean peaches accoriding to cultivars. J Korean Soc Food Sci Nutr, 41, 221-226

6. Globerman H, Navok T, Chevion M (1984) Haemolysis in a G6PD-deficient child induced by eating unripe peaches. Eur J Haematol, 33, 337-341

7. Pressey R, Hinton DM, Avants JK (1971) Development of polygalacturonase activity and solubilization of pectin in peaches during ripening. J Food Sci, 36, 1070-1073

8. Kim HJ (2007) Isolation and characterization of active whitening compound from Prunus persica. MS Thesis, Korea University, Korea, p 31-51

9. Rehman Z, habib F, Shah WH (2004) Utilization of potato peels extract as a natural antioxidant in soy bean oil. Food Chem, 85, 215-220

10. Coleman MD, Fernandes S, Khanderia L (2003) A preliminary evaluation of a novel method to monitor a triple antioxidant combination (vitamins $\mathrm{E}, \mathrm{C}$ and a-lipoic acid) in diabetic volunteers using in vitro methaemoglobin formation. Environ Toxicol Pharmacol, 14, 69-75

11. Olas B, Wachowicz B (2002) Resveratrol and vitamin $\mathrm{C}$ as antioxidants in blood platelets. Thromb Res, 106, 143-148

12. Monsen ER (2000) Dietary reference intakes for the antioxidant nutrients: vitamin $\mathrm{C}$, vitamin $\mathrm{E}$, selenium, and carotenoids. J Am Diet Assoc, 100, 637-640

13. Marquina MA, Corao GM, Araujo L, Buitrago D, Sosa M (2002) Hyaluronidase inhibitory activity from the polyphenols in the fruit of blackberry (Rubus fruticosus B.). Fitoterapia, 73, 727-729

14. Lee NH, Lee SJ, Jung DS, Bu HJ, Yang HC, Riu KZ (2001) Screening of the tyrosinase inhibition and hyaluronidase inhibition activities, and radical scavenging effects using plants in Cheju. Kor J Pharmacogn, 32, 175-180 
15. Cha BC, Lee EH (2004) Antioxidant and antiinflammation activities of Prunus persica tree extracts. Korean J Medicinal Crop Sci, 12, 289-294

16. Lee KH, Jang HJ, Lee YJ, Choi JH (2014) Changes in the chemical components and antioxidant activity of Peach (Prunus persica L. Batsch) by hot air treatment. Korean J Food Nutr, 27, 219-224

17. Park KK (2008) Studies on Functions of Prunus Persica to Develop as the Functional Food. Report of Rural Development Administration, RDA SE0000106586

18. Park YK, Choi SH, Kim SH, Han JG, Chung HG (2007) Changes in antioxidant activity, total phenolics and vitamin C content during fruit ripening in Rubus occidentalis. Korean J Plant Res, 20, 461-465

19. Lim SJ, Hwang HS, Shin YJ (2016) Physicochemical properties and antioxidant activities of 'Seolhyang' and 'Janghee' strawberries from different ripening stages grown in Korea. J East Asian Soc Dietary Life, 26, 80-87

20. Kim DM, Kim KH, Kim YS, Koh JH, Lee KH, Yook HS (2012) A study on the development of cosmetic materials using unripe peaches seed extracts. J Korean Soc Food Sci Nutr, 41, 110-115

21. Hwang JR, Hwang IK, Kim SN (2015) Quantitative analysis of various carotenoids from different colored paprika using UPLC. Korean J Food Sci Technol, 47, $1-5$

22. Folin O, Denis W (1912) On phosphotungsticphosphomolybdic compounds as color reagents. J Biol Chem, 12, 239-243

23. Zhishen J, Mengcheng T, Jianming W (1999) The determination of flavonoid contents in mulberry and their scavenging effects on superoxide radicals. Food Chem, 64, 555-559

24. Singleton VL, Orthofer R, Lamuela-Raventos RM (1999) Analysis of total phenols and other oxidation substrates and antioxidants by means of Folin-Ciocalteu reagent. Methods Enzymol, 299, 152-178

25. Blois MS (1958) Antioxidant determinations by the use of a stable free radical. Nature, 181, 1199-1200

26. Benzie IFF, Strain JJ (1996) The ferric reducing ability of plasma (FRAP) as a measure of "antioxidant power": the FRAP assay. Anal Biochem, 239, 70-76
27. Apak R, Guclu K, Ozyurek M, Karademir SE (2004) Novel total antioxidant capacity index for dietary polyphenols and vitamins $\mathrm{C}$ and $\mathrm{E}$, using their cupric ion reducing capability in the presence of neocuproine: CUPRAC method. J Agric Food Chem, 52, 7970-7981

28. Re R, Pellegrini N, Proteggente A, Pannala A, Yang M, Rice-Evans C (1999) Antioxidant activity applying an improved ABTS radical cation decolorization assay. Free Radical Biol Med, 26, 1231-1237

29. Lu Y, Foo LY (2000) Antioxidant and radical scavenging activities of polyphenols from apple pomace. Food Chem, $68,81-85$

30. Lee DJ, Jeon IH, Kim HS, Cho IY, Jang SI (2012) Antioxidative and anti-inflammatory effect of ethanol extract from Duchesnea chrysantha. Korean J Orient Physiol Pathol, 26, 59-66

31. Kim YJ, Son DY (2013) Antioxidant and anticancer properties of hot water and ethanol extracts from the roots of Smilax china L.. Korean J Food Preserv, 20, 691-698

32. Lee JH, Park AR, Choi DW, Kim JD, Kim JC, Ahn JH, Lee HY, Choe M, Choi KP, Shin IC, Park HJ (2011) Analysis of chemical compositions and electron-donating ability of 4 Korean wild Sannamuls. Korean J Medicinal Crop Sci, 19, 111-116

33. Lee YM, Bae JH, Kim JB, Kim SY, Chung MN, Park MY, Ko JS, Song J, Kim JH (2012) Changes in the physiological activities of four sweet potato varieties by cooking condition. Korean J Nutr, 45, 12-19

34. Lee YS (2007) Antioxidant and physiologocal activity of extracts of Angelica dahurica leaves. Korean J Food Preserv, 14, 78-86

35. Yoo KM, Kim DO Lee CY (2007) Evaluation of different methods of antioxidant measurement. Food Sci Biotechnol, 16, 177-182

36. Rhim TJ, Choi MY, Park HJ (2012) Antioxidative activity of Rumex crispus L. extract. Korean J Plant Res, 25, 568-577

37. Jung HW, Park YK (2006) Inhibitory effect of Coptidis Rhizoma on LPS-induced production of nitric oxide and TNF- $a$ in mouse macrophage cells. Korean J Herbology, $21,165-173$ 